\title{
Antimicrobial Susceptibility Profiles among Escherichia coli Strains Isolated from Athi River Water in Machakos County, Kenya
}

\author{
Peris Wambugu ${ }^{*}$, Michael Habtu${ }^{1}$, Phyllis Impwi ${ }^{1}$, Viviene Matiru², John Kiiru ${ }^{3}$ \\ ${ }^{1}$ Jomo Kenyatta University of Agriculture and Technology, Institute of Tropical Medicine and Infectious \\ Diseases, Nairobi, Kenya \\ ${ }^{2}$ Department of Botany, Sub-Department of Medical Microbiology, Jomo Kenyatta University of Agriculture \\ and Technology, Nairobi, Kenya \\ ${ }^{3}$ Centre of Microbiology Research, Kenya Medical Research Institute, Nairobi, Kenya \\ Email: *perhizz@yahoo.com
}

Received 23 August 2015; accepted 22 September 2015; published 25 September 2015

Copyright (C) 2015 by authors and Scientific Research Publishing Inc.

This work is licensed under the Creative Commons Attribution International License (CC BY). http://creativecommons.org/licenses/by/4.0/

(c) $\underset{\mathrm{EY}}{\mathrm{EY}}$ Open Access

\begin{abstract}
Antimicrobial use in agriculture, livestock and human health has increased over the years leading to the increase in antimicrobial resistance that can also find its way to the aquatic environment. Rivers can act as reservoirs of highly resistant strains and facilitate the dissemination of multidrug resistant (MDR) strains to animals and humans using water. A total of 318 water samples were collected from six different sampling points along Athi River and $E$. coli isolates were subjected to Kirby-Bauer diffusion method for antimicrobial susceptibility testing. The total mean coliform count of the sampled sites was $2.7 \times 10^{4}(\mathrm{cfu} / \mathrm{mL})$. E. coli isolates were most resistant to ampicillin (63.8\%) and most susceptible to gentamicin (99.4\%). MDR strains (resistance to $\geq 3$ classes of antibiotics) accounted for $65.4 \%$ of all the isolates. The site recorded to have human industrial and agricultural zone activities had strains that were significantly more resistant to ampicillin, cefoxitin, amoxicillin/clavulanic acid $(P \leq 0.05)$ than isolates from the section of the river traversing virgin land and land with minimum human activities. This study indicates that $E$. coli strains isolated from Athi River were highly MDR and most resistant to some antimicrobial classes (ampicillin and cefoxitin) which constitute a potential risk to human and animal health.
\end{abstract}

\section{Keywords}

Antimicrobials, Athi River, E. coli, Multi-Drug Resistance, Susceptibility Test

\footnotetext{
"Corresponding author.
}

How to cite this paper: Wambugu, P., Habtu, M., Impwi, P., Matiru, V. and Kiiru, J. (2015) Antimicrobial Susceptibility Profiles among Escherichia coli Strains Isolated from Athi River Water in Machakos County, Kenya. Advances in Microbiology, 5, 711-719. http://dx.doi.org/10.4236/aim.2015.510074 


\section{Introduction}

Rise in resistance to multiple drugs among $E$. coli is a major concern both in developed and developing countries. Evolutionary pressure arising from widespread use of antimicrobials has contributed to the development of multi-drug resistant (MDR) strains and the spread of resistance between bacterial species. The major cause of the emergence of resistant bacteria is the misuse and overuse of antimicrobials [1]. Contamination of water sources as a result of pollution with faecal bacteria has potential to spread highly resistant strains [2]-[5]. Microbes in water have a greater potential as source of infectious bacteria to people who use the water for recreational activities, fishing, drinking, bathing and irrigation of crops, especially those eaten raw [6]. Therefore, water pollution with MDR strains, especially those suspected to be of human origin requires evaluation [7] [8]. E. coli is an important indicator organism for faecal pollution in environmental waters and has also been useful in monitoring antimicrobial resistance patterns in Gram-negative bacteria. We evaluated contamination levels at multiple sampling sites and antimicrobial susceptibility profiles among $E$. coli strains obtained from Athi River water. Athi River in Machakos County is a heavily polluted water system mainly as a result of contamination from sewerage originating from Westlands and Kasarani areas in Nairobi [9]. However, little is known about the level of microbial contamination and antimicrobial susceptibility patterns from this river using E. coli as indicator organism. The aim of this cross-sectional study was to determine antimicrobial susceptibility profiles among E. coli isolated from different sections of this river.

\section{Materials and Methods}

\subsection{Study Area}

The study was carried out along the banks of River Athi within the Athi River Township in Machakos County. Athi River is the second longest river in Kenya after River Tana. It has a total length of approximately $400 \mathrm{~km}$ and drains a basin area of $70,000 \mathrm{~km}^{2}$. The river rises at $1^{\circ} 42^{\prime} \mathrm{S}$ as Athi River and enters the Indian Ocean as River Galana. The river flows across the Kapiti and Athi plains, through the Athi River town, takes a northeast direction and is met by the River Nairobi [10].

\subsection{Sampling Points}

The sampling points were selected based on prevailing human activities such as washing, drinking points for livestock, points where residents fetch water for domestic use, and points heavily contaminated with industrial effluent. Sampling was also done along sections of the river passing through virgin lands that have no obvious evidence of recent interference by human activity, agriculture or settlement as shown in Table 1 and Figure 1.

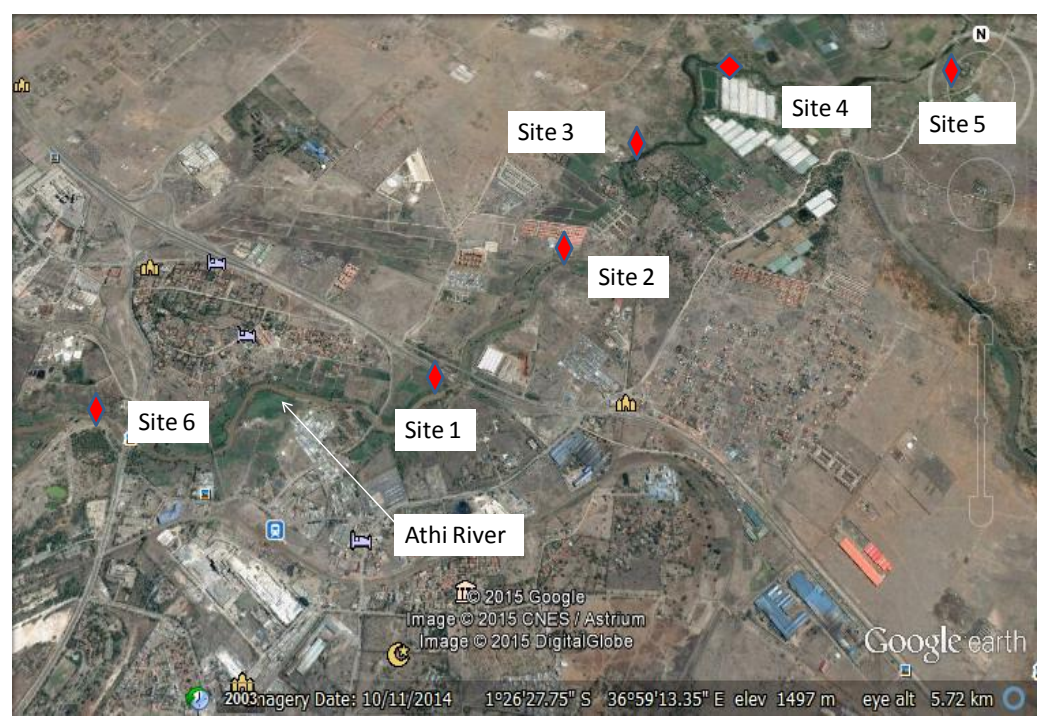

Figure 1. Aerial view of sampling sites along Athi River in Athi River Town, Machakos from Google Earth. 
Table 1. Activities on different sites where water was sampled.

\begin{tabular}{ll}
\hline Site & Activities on site \\
\hline Site 1 (domestic use) & Water for domestic use, washing clothes \\
Site 2 (settlements) & Informal and formal human settlements \\
Site 3 (virgin land) & no apparent human, industrial or agricultural activities \\
Site 4 (sewerage effluent) & Sewage treatment plant in close vicinity \\
Site 5 (near road and farming) & Close to tarmac road. Water also used for flower farming \\
Site 6 (industrial zone) & $\begin{array}{l}\text { Near the industrial zone (cement factory in close vicinity), water } \\
\text { used for bathing, watering flowers, livestock watering in shallow } \\
\text { edges of the river }\end{array}$ \\
\hline
\end{tabular}

\subsection{Sample Collection}

Water samples were collected from each site in varying dates between September 2014 and January 2015. Sampling of each site was done only once. A total of 53 samples (500 mL each) were taken from each site during dry and wet seasons to make a total of 318 water samples. Samples were collected using sterile plastic bottles. These bottles were lowered into the water body to a maximum depth of $30 \mathrm{~cm}$ before withdrawal. The samples were transported to Kenya Medical Research Institute Centre for Microbiology laboratory in an insulated cool box $\left(4^{\circ} \mathrm{C}-8^{\circ} \mathrm{C}\right)$ and processed within $24 \mathrm{hrs}$.

\subsection{Colony Forming Units and Isolation of E. coli}

Multiple tube fermentation technique was used to enumerate fecal coliforms. For isolation of E. coli, $25 \mathrm{~mL}$ of sample water was inoculated into $225 \mathrm{~mL}$ of buffered peptone water (BPW) and incubated at $37^{\circ} \mathrm{C}$ for $24 \mathrm{hrs}$. A loop full of broth was then streaked on MacConkey's agar and incubated at $37^{\circ} \mathrm{C}$ for $24 \mathrm{hrs}$. Suspect colonies were identified as E. coli using standard morphological and biochemical tests for Enterobacteriaceae.

\subsection{Susceptibility Testing}

Antimicrobial susceptibility testing was done using the disc diffusion method. Isolates were tested for susceptibility towards amoxicillin/clavulanic acid (20/10 $\mu \mathrm{g})$ ampicillin $(10 \mu \mathrm{g})$, aztreonam (30 $\mu \mathrm{g})$, cefotaxime (30 $\mu \mathrm{g})$, cefepime $(30 \mu \mathrm{g})$, cefoxitin (30 $\mu \mathrm{g})$ ceftazidime $(30 \mu \mathrm{g})$, cefpodoxime $(10 \mu \mathrm{g})$, tetracycline $(30 \mu \mathrm{g})$, gentamicin $(10 \mu \mathrm{g})$, trimethoprim $(5 \mu \mathrm{g})$, chloramphenicol $(30 \mu \mathrm{g})$, ciprofloxacin $(5 \mu \mathrm{g})$, nalidixic acid (30 $\mu \mathrm{g})$, streptomycin $(10 \mu \mathrm{g})$ and sulfamethoxazole $(50 \mu \mathrm{g})$. For each batch of isolates tested, E. coli 25922 was used as a control strain to check for disc potency and to assess the quality of the media. Zone sizes and susceptibility profiles were interpreted using Clinical Laboratory Standard Institute (CLSI) standard guidelines. Isolates were categorized as either fully susceptible, resistant to 1 or 2 classes of antimicrobials or MDR (resistant to three or more classes of antimicrobials).

\subsection{Statistical Analysis}

Statistical analysis was conducted using the SPSS Version 20.0 software. Descriptive analysis was done to determine the prevalence various susceptible phenotypes. Chi-square test (significance set at $\mathrm{P} \leq 0.05$ ) and odds ratio with corresponding 95\% confidence interval was used to analyse association between distribution of specific antimicrobial susceptibility profiles and site characteristics where the water samples were collected.

\section{Results}

\subsection{Coliform Forming Units (CFUs)}

The average coliform counts $(\mathrm{cfu} / \mathrm{mL})$ for the six sites were $2.7 \times 10^{4}$. Location near sewage treatment plant (site 4) had most CFUs compared to other sites sampled. Numbers of CFUs were higher in wet season than dry season as shown in Table 2. 
Table 2. Mean load of coliforms along Athi River (cfu/mL) in Machakos, Kenya.

\begin{tabular}{lllll}
\hline Group variables & Total cfu/mL & Mean cfu/mL & Dry days cfu/mL & Rainy days cfu/mL \\
\hline Sites & & & & \\
Site 1 (domestic use) & $2.79 \times 10^{5}$ & $5.2 \times 10^{3}$ & $1.2 \times 10^{5}$ & $1.5 \times 10^{5}$ \\
Site 2 (settlements) & $8.8 \times 10^{4}$ & $1.6 \times 10^{3}$ & $4.3 \times 10^{4}$ & $4.5 \times 10^{4}$ \\
Site 3 (virgin land) & $5.0 \times 10^{4}$ & $9.5 \times 10^{2}$ & $2.4 \times 10^{4}$ & $2.6 \times 10^{4}$ \\
Site 4 (sewerage effluent) & $5.0 \times 10^{5}$ & $9.5 \times 10^{3}$ & $2.0 \times 10^{5}$ & $3.0 \times 10^{5}$ \\
Site 5 (near road and farming) & $1.0 \times 10^{5}$ & $1.9 \times 10^{3}$ & $5.0 \times 10^{4}$ & $5.2 \times 10^{4}$ \\
Site 6 (industrial zone) & $4.0 \times 10^{5}$ & $7.6 \times 10^{3}$ & $2.0 \times 10^{5}$ & $2.0 \times 10^{5}$ \\
\hline
\end{tabular}

\subsection{Antimicrobial Susceptibility among E. coli Isolates to Selected Antimicrobials}

Distribution of antimicrobial susceptibilities of E. coli from Athi River is presented in Figure 2. High resistances were observed for ampicillin (63.8\%), cefoxitin (46.9\%), amoxicillin/clavulanic acid (46.2\%) and sulfamethazole $(44 \%)$. Least resistances were observed against gentamicin $(<1 \%)$, cefepime $(1.9 \%)$, ceftazidime (2.5\%) and chloramphenicol (3.8\%).

\subsection{Resistance of E. coli Isolates between the Sampling Points (Sites)}

Antimicrobial resistance patterns among isolates recovered from each of the six sampling sites are shown in Table 3. Highest resistance to ampicillin (79.2\%) were observed among isolates recovered from sections of the river close to tarmac road where water was used for flower farming (site 5) and industrial zone (site 6) while sections where water was for domestic use and washing clothes (site 1) had the lowest observed resistance (47.2\%). Resistance to cefoxitin was highest in industrial zone (site 6, 73.6\%), and lowest in virgin land (site 3, 30.2\%). Resistance to amoxicillin/clavulanic acid was highest in industrial zone (site 6, 81.1\%), and lowest in section of the river having formal and informal settlements (site 2, 32.1\%). Resistance to sulfamethazole was highest in virgin land (site 3, 52.8\%) and lowest in site 2 (34\%). Highest resistance to ciprofloxacin (20.8\%) was observed among isolates obtained from water for domestic use (site 1) and lowest in (0\%) site 5 where water was utilised for farming and was closest to the tarmac road. Interestingly, highest resistance to cefepime (a fourth generation cephalosporin) was recorded in the virgin land (site 3, 9.4\%) and lowest in all the other sites including the industrial zone and the section contaminated with sewerage effluent. Highest resistance to aztreonam was recorded among isolates obtained from water utilised for domestic purposes (site 1, 13.2\%) while the lowest resistances were observed among isolates recovered from the river section closest to the tarmac road where water was also utilised for flower farming (site 5, 5.7\%).

\subsection{Distribution of Multiple Drug Resistance (MDR) Strains}

Antimicrobial resistant phenotypes are presented in Table 4. Majority (37.1\%) of the isolates were resistant to four to five antimicrobials. Isolates from water contaminated with industrial waste (site 6) were more likely to exhibit resistance to more than three classes of antimicrobials than those from virgin land (site 3) $(\mathrm{P}=0.001$, CI 1.99 - 17.06).

Resistance against different antimicrobials observed across different sites were not significantly different from those observed among isolates recovered from river section going through virgin land (site 3). However, isolates from industrial site (site 6) had higher resistance to amoxicillin/clavulanic acid than those from virgin land ( $\mathrm{P}<0.001$, CI 3.43 - 20.41). Isolates from this site were also likely to be MDR compared to those from virgin land (P 0.001, CI 1.99 - 17.06).

\section{Discussion}

This study showed that areas with human, animal, agricultural or industrial activities had significantly higher CFUs than those with minimal activities. Areas located near a sewerage treatment plant recorded a significantly 


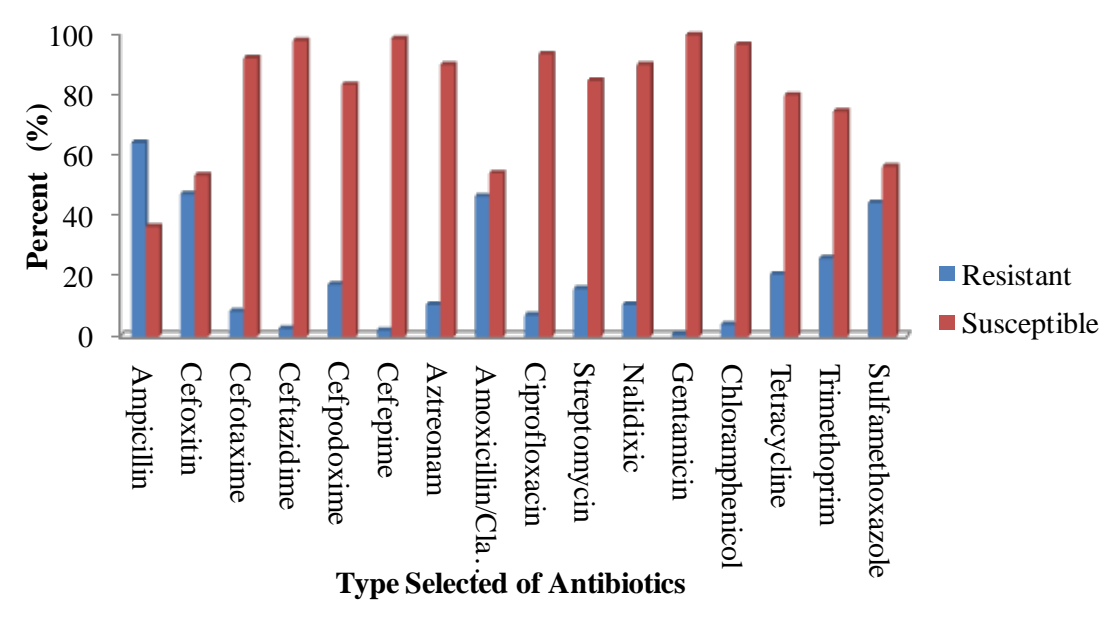

Figure 2. Percentage of E. coli isolates showing resistance to various antimicrobials.

Table 3. Distribution of resistance.

\begin{tabular}{|c|c|c|c|c|c|c|c|c|c|c|c|c|c|c|c|c|}
\hline \multirow{2}{*}{$\begin{array}{l}\text { Sampling sites } \\
\text { Sites }\end{array}$} & \multicolumn{16}{|c|}{ Isolates resistant to various antimicrobials [(numbers (\%)] } \\
\hline & Amp & Fox & Ctx & Caz & Cpd & Fep & Atm, & Amc & Cip, & S & $\mathrm{Na}$ & Cn & C & Te & Ctx & $\mathbf{W}$ \\
\hline $\begin{array}{l}\text { Site } 1 \\
\text { (domestic use) }\end{array}$ & $\begin{array}{l}25 \\
(47.2)\end{array}$ & $\begin{array}{l}25 \\
(47.2)\end{array}$ & $\begin{array}{l}10 \\
(18.9)\end{array}$ & $\begin{array}{l}3 \\
(5.7)\end{array}$ & $\begin{array}{l}10 \\
(18.9)\end{array}$ & $\begin{array}{l}1 \\
(1.9)\end{array}$ & $\begin{array}{l}7 \\
(13.2)\end{array}$ & $\begin{array}{l}20 \\
(37.7)\end{array}$ & $\begin{array}{l}11 \\
(20.8)\end{array}$ & $\begin{array}{l}4 \\
(7.5)\end{array}$ & $\begin{array}{l}6 \\
(11.3)\end{array}$ & $\begin{array}{l}1 \\
(1.9)\end{array}$ & $\begin{array}{l}4 \\
(7.5)\end{array}$ & $\begin{array}{l}17 \\
(32.1)\end{array}$ & $\begin{array}{l}26 \\
(49.1)\end{array}$ & $\begin{array}{l}18 \\
(34)\end{array}$ \\
\hline $\begin{array}{l}\text { Site } 2 \\
\text { (settlements) }\end{array}$ & $\begin{array}{l}30 \\
(56.6)\end{array}$ & $\begin{array}{l}21 \\
(39.6)\end{array}$ & $\begin{array}{l}4 \\
(7.5)\end{array}$ & $\begin{array}{l}0 \\
(0)\end{array}$ & $\begin{array}{l}9 \\
(17)\end{array}$ & $\begin{array}{l}0 \\
(0)\end{array}$ & $\begin{array}{l}5 \\
(9.4)\end{array}$ & $\begin{array}{l}17 \\
(32.1)\end{array}$ & $\begin{array}{l}1 \\
(1.9)\end{array}$ & $\begin{array}{l}5 \\
(9.4)\end{array}$ & $\begin{array}{l}5 \\
(9.4)\end{array}$ & $\begin{array}{l}0 \\
(0)\end{array}$ & $\begin{array}{l}1 \\
(1.9)\end{array}$ & $\begin{array}{l}8 \\
(15.1)\end{array}$ & $\begin{array}{l}18 \\
(34)\end{array}$ & $\begin{array}{l}8 \\
(15.1)\end{array}$ \\
\hline $\begin{array}{l}\text { Site } 3 \\
\text { (virgin land) }\end{array}$ & $\begin{array}{l}35 \\
(66.0)\end{array}$ & $\begin{array}{l}16 \\
(30.2)\end{array}$ & $\begin{array}{l}3 \\
(5.7)\end{array}$ & $\begin{array}{l}4 \\
(7.5)\end{array}$ & $\begin{array}{l}9 \\
(17)\end{array}$ & $\begin{array}{l}5 \\
(9.4)\end{array}$ & $\begin{array}{l}9 \\
(17)\end{array}$ & $\begin{array}{l}18 \\
(34)\end{array}$ & $(7.5)$ & $\begin{array}{l}11 \\
(20.8)\end{array}$ & $\begin{array}{l}4 \\
(7.5)\end{array}$ & $\begin{array}{l}1 \\
(1.9)\end{array}$ & $\begin{array}{l}4 \\
(7.5)\end{array}$ & $\begin{array}{l}10 \\
(18.9)\end{array}$ & $\begin{array}{l}28 \\
(52.8)\end{array}$ & $\begin{array}{l}13 \\
(24.5)\end{array}$ \\
\hline $\begin{array}{l}\text { Site } 4 \text { (sewerage } \\
\text { effluent) }\end{array}$ & $\begin{array}{l}29 \\
(54.7)\end{array}$ & $\begin{array}{l}17 \\
(32.1)\end{array}$ & $\begin{array}{l}7 \\
(13.2)\end{array}$ & $\begin{array}{l}0 \\
(0)\end{array}$ & $\begin{array}{l}8 \\
(15.1)\end{array}$ & $\begin{array}{l}0 \\
(0)\end{array}$ & $\begin{array}{l}5 \\
(9.4)\end{array}$ & $\begin{array}{l}22 \\
(41.5)\end{array}$ & $(7.5)$ & $\begin{array}{l}8 \\
(15.1)\end{array}$ & $\begin{array}{l}5 \\
(9.4)\end{array}$ & $\begin{array}{l}0 \\
(0)\end{array}$ & $\begin{array}{l}2 \\
(3.8)\end{array}$ & $\begin{array}{l}18 \\
(34)\end{array}$ & $\begin{array}{l}22 \\
(41.5)\end{array}$ & $\begin{array}{l}17 \\
(32.1)\end{array}$ \\
\hline $\begin{array}{l}\text { Site } 5 \text { (near road } \\
\text { and farming }\end{array}$ & $\begin{array}{l}42 \\
(79.2)\end{array}$ & $\begin{array}{l}31 \\
(58.5)\end{array}$ & $\begin{array}{l}1 \\
(1.9)\end{array}$ & $\begin{array}{l}0 \\
(0)\end{array}$ & $\begin{array}{l}7 \\
(13.2)\end{array}$ & $\begin{array}{l}0 \\
(0)\end{array}$ & $\begin{array}{l}3 \\
(5.7)\end{array}$ & $\begin{array}{l}27 \\
(50.9)\end{array}$ & $\begin{array}{l}0 \\
(0)\end{array}$ & $\begin{array}{l}6 \\
(11.3)\end{array}$ & $\begin{array}{l}4 \\
(7.5)\end{array}$ & $\begin{array}{l}0 \\
(0)\end{array}$ & $\begin{array}{l}1 \\
(1.9)\end{array}$ & $\begin{array}{l}5 \\
(9.4)\end{array}$ & $\begin{array}{l}19 \\
(35.8)\end{array}$ & $\begin{array}{l}15 \\
(28.3)\end{array}$ \\
\hline $\begin{array}{l}\text { Site } 6 \\
\text { (industrial zone) }\end{array}$ & $\begin{array}{l}42 \\
(79.2)\end{array}$ & $\begin{array}{l}39 \\
(73.6)\end{array}$ & $\begin{array}{l}1 \\
(1.9)\end{array}$ & $\begin{array}{l}1 \\
(1.9)\end{array}$ & $\begin{array}{l}11 \\
(20.8)\end{array}$ & $\begin{array}{l}0 \\
(0)\end{array}$ & $\begin{array}{l}4 \\
(7.5)\end{array}$ & $\begin{array}{l}43 \\
(81.1)\end{array}$ & $\begin{array}{l}2 \\
\text { (3.8) }\end{array}$ & $\begin{array}{l}16 \\
(30.2)\end{array}$ & $\begin{array}{l}9 \\
(17)\end{array}$ & $\begin{array}{l}0 \\
(0)\end{array}$ & $\begin{array}{l}0 \\
(0)\end{array}$ & $\begin{array}{l}6 \\
(11.3)\end{array}$ & $\begin{array}{l}27 \\
(50.9)\end{array}$ & $\begin{array}{l}11 \\
(20.8)\end{array}$ \\
\hline
\end{tabular}

N.B: Amp: Ampicillin, Fox: Cefoxitin, Ctx: Cefotaxime, Caz: Ceftazidime, Cpd: Cefpodoxim, Fep: Cefepime, Atm: Aztreonam, Amc: Amoxicillin/clavulanic acid, Cip: Ciprofloxacin, S: Streptomycin, Na: Nalidixic, Cn: Gentamicin, C: Chloramphenicol, Te: Tetracycline, Ctx: Sulfamethoxaz, W: Trimethoprim.

Table 4. Percentage of E. coli showing resistance to classes of antimicrobials.

\begin{tabular}{lllllll}
\hline \multirow{2}{*}{ Site characteristics } & \multicolumn{5}{c|}{ Antimicrobial resistance phenotype n (\%) } \\
\cline { 2 - 7 } & Fully susceptible & MDR (1) & MDR (2) & MDR (3) & MDR (4 - 5) & MDR (>5) \\
\hline All sites & $17(5.3)$ & $41(12.9)$ & $52(16.4)$ & $65(20.4)$ & $118(37.1)$ & $25(7.9)$ \\
Site 1 (domestic use) & $1(1.9)$ & $6(11.3)$ & $15(28.3)$ & $5(9.4)$ & $18(34.0)$ & $8(15.1)$ \\
Site 2 (settlements) & $7(13.2)$ & $10(18.9)$ & $10(18.9)$ & $9(17.0)$ & $16(30.2)$ & $1(1.9)$ \\
Site 3 (virgin land) & 0 & $10(18.9)$ & $10(18.9)$ & $9(17.0)$ & $20(37.7)$ & $4(7.5)$ \\
Site 4 (sewerage effluent) & $4(7.5)$ & $6(11.3)$ & $10(18.9)$ & $10(18.9)$ & $20(37.7)$ & $3(5.7)$ \\
Site 5 (near road and farming & $4(7.5)$ & $7(13.2)$ & $5(9.4)$ & $19(35.8)$ & $15(28.3)$ & $3(5.7)$ \\
Site 6 (industrial zone) & $1(1.9)$ & $2(3.8)$ & $2(3.8)$ & $13(24.5)$ & $29(54.7)$ & $6(11.3)$ \\
\hline
\end{tabular}

N.B: MDR 1: Resistance to one antimicrobial, MDR 2: Resistance to two antimicrobials, MDR 3: Resistance to three antimicrobials, MDR 3: Resistance to three antimicrobials, MDR 4 - 5: Resistance to four and five antimicrobials, MDR > 5: Resistance to five or more antimicrobials. 
high CFUs compared to other sites. Similar results have been obtained in a study conducted in Germany where microbial contamination of water passing through megacities was assessed [11]. Downstream from this area, the number of coliforms declined with those of virgin land showing least contamination compared to other sites. As expected, these results showed that water near the sewerage plant was more polluted. This observation indicates possible inefficiencies of the treatment plant. CFUs in wet season were higher than the dry season. These observations are similar to those obtained in previous studies and can be suggest a possible increase in amount of contaminated surface run offs into the river system during rainy period [9] [12].

The current study also reported high number of resistant bacteria especially for ampicillin, cefoxitin, amoxicillin/clavulanic acid and sulfamethazole. These results are close to those published in related studies conducted in Mexico, India, Kenya and Nigeria [12]-[15]. This is a public health concern because increase in resistant bacteria may complicate treatment of infections arising from such strains. Cefoxitin resistance was high (46.9\%) compared to other studies done in the past with an exception of study carried out in Philippines that sampled water hand pumps and reported cefoxitin resistance of 59\% [15]-[20]. High resistance to cefoxitin with concomitant low resistance to cephalosporins may indicate that majority of these isolates carry inducible chromosomal encoded ampCs gene as suggested in other studies carried out in India [21] [22]. Ciprofloxacin resistance was highest in section of river used for domestic purposes (site 1). We also observed resistance to third generation cephalosporins such as cefotaxime (8.2\%), ceftazidime (2.5\%) and to cefepime (1.9\%). These antibiotics are used in treating complicated systemic bacterial infections and therefore, their potency is of immense clinical value [23]. Similar results have been reported in related studies in Turkey, United Kingdom and in China [24]-[26]. $\beta$-lactams make up to $40 \%$ of the prescribed antimicrobials in an outpatient setting with cephalosporins making up to a total of $14 \%$ of prescriptions in same setting [27] which can mean that resistance to these antibiotics is worrying especially if strains exhibiting resistance to these agents have found their way into the environment.

Resistance prevalence to sulfamethazole was high (44\%) which is similar to related study done in Poland that reported resistance of $94.4 \%$ among integron-harbouring $E$. coli from upstream water [28]. Amoxillin/clavulanic acid resistance was $46.2 \%$ which was also high. Reports on bacteria resistant to amoxicillin/clavulanic acid in clinical settings emerged as early as 1987 and majority of these were isolated from patients who were receiving this antibiotic combination as a first line treatment for respiratory infections [29]. Resistance to this antimicrobial is worrying because this antimicrobial is in World health organization list of agents that are frequently used for empiric treatment of many infections. It is therefore possible that isolates showing resistance to this antibiotic combination have a clinical background [7] [13] [30].

In this study, $65.4 \%$ of $E$. coli isolates showed resistance to three or more classes of antimicrobials screened. Majority of the isolates were resistant to four to five antimicrobials (54.7\%). Presence of highly MDR strains in the water system could be interpreted to mean that Athi River is a significant reservoir for MDR strains. Related studies conducted in China and Oregon have identified similar river systems as a significant risk factors for highly MDR strains [20] [31] [32]. Other studies have similarly identified highly resistant strains from river sections polluted with industrial effluent [4] [33] [34]. Similar to our findings, a related study showed that high MDR strains are more common from water ways contaminated with runoffs from land occupied by animal and human, and those with urban and industrial sewerage [30]. More so, the study showed that sections of river that showed no apparent human and agricultural activities had no E. coli isolates which were fully susceptible to antimicrobials. Although we did not conduct any experiments to link the MDR isolates to infections, the high antimicrobial resistance pattern observed highly suggest that some of these strains may have a clinical background where they are subjected to strong selection pressure due to heavy use of antimicrobials. From the study, Athi River water was found to be polluted with high levels of faecal coliforms and the water may therefore be unfit for human use. There is a need for better waste management in Athi River town and public sensitization on ways to treat water as to make it safe for use.

\section{Conclusion}

The faecal contamination of Athi River was high with the most polluted regions near the sewerage treatment plant and the industrial zone. The ability of $E$. coli isolates to be resistant to third generation cephalosporins, amoxicillin/clavulanic acid and sulfamethoxazole which are used in treatment of gram negative infections is a public health concern. The study showed that environmental isolates in Kenya are resistant to antimicrobials and much focus should be placed to study aquatic microbial environment as much as clinical environment. This will 
be useful in knowing the pattern of resistance in the environment, the genes responsible and whether resistance can be transferred from one E. coli isolate to another. This will then be important in developing surveillance systems to assess the extent of resistance in aquatic environment in Kenya and Africa. The study was helpful in knowing antimicrobial resistance in the second longest river in Kenya which can be used as an indicator showing the extent of antimicrobial resistance in environment.

\section{Acknowledgements}

I would like to thank centre of microbiology in Kenya medical research institute personnel for offering me lab space and equipments and Mr. Igor Markovic who made it possible to enrol for masters program and provided for research work.

\section{Author Contributions}

PW came up with the concept for the work and designed the study. She did the lab work and drafted the manuscript. PI assisted in lab work. JK participated in the study design and helped in drafting the manuscript. VM corrected the proposal and helped in its coordination. MH assisted in manuscript preparation. All authors read and approved final manuscript.

\section{Authors' Information}

PW is a master's student in Kenya studying medical microbiology together with PI. MH is a public health master's student. Prof. VM is the dean of biological sciences in Jomo Kenyatta University of agriculture and technology who has a vast experience in proposal development and microbial techniques. Dr. JK helped in actualizing the study and fine tuning the manuscript. He is a researcher in Centre of Microbiology Research Centre in Kenya Medical Research Institute.

\section{Conflict of Interest}

None.

\section{Ethical Approval}

Approved.

\section{References}

[1] Sean, D. and Pitman, M. (2004) Antibiotic Resistance. www.detectingdesign.com

[2] Kummerer, K. (2009) Chemosphere Antibiotics in the Aquatic Environment-A Review-Part I. Chemosphere [Internet], 75, 417-434.

[3] Kummerer, K. (2009) Chemosphere Antibiotics in the Aquatic Environment-A Review-Part II. Chemosphere [Internet]. 75, 435-441.

[4] Kummerer, K. (2004) Resistance in the Environment. Chemosphere, 54, 311-320. http://dx.doi.org/10.1007/978-3-662-09259-0 18

[5] Xi, C., Zhang, Y., Marrs, C.F., Ye, W., Simon, C., Foxman, B., et al. (2009) Prevalence of Antibiotic Resistance in Drinking Water Treatment and Distribution Systems. Applied and Environmental Microbiology, 75, 5714-5718. http://dx.doi.org/10.1128/AEM.00382-09

[6] Molloy, S.L., Whitman, R.L., Shively, D.A., Nevers, M.B., Schwab, D.J. and Rose, J.B. (2006) Modeling the Transport and Inactivation of E. coli and Enterococci in the Near-Shore Region of Lake Michigan. Environmental Science \& Technology, 40, 5022-5028. http://dx.doi.org/10.1021/es060438k

[7] Hawkey, P.M., Jones, A.M., Birmingham, B., Strategic, M. and House, M. (2009) The Changing Epidemiology of Resistance. Journal of Antimicrobial Chemotherapy, 64, 3-10. http://dx.doi.org/10.1093/jac/dkp256

[8] WHO (2006) Guidlines for the Safe Use of Waste Water, Excreta and Grey Water Volume 2 Wastewater Use in agriculture. WHO, Geneva.

[9] Musyoki, A.M., Suleiman, M.A., Mbithi, J.N. and Maingi, J.M. (2013) Water-Borne Bacterial Pathogens in Surface Waters of Nairobi River and Health Implications to Communities Downstream Athi River. International Journal of 
Life Sciences Biotechnology and Pharma Research, 3, L4-L10.

[10] Wikipedia (2014) Athi-Galana-Sabaki River.

[11] Abraham, W. (2011) Megacities as Sources for Pathogenic Bacteria in Rivers and Their Fate Downstream. International Journal of Microbiology, 2011, Article ID: 798292. http://dx.doi.org/10.1155/2011/798292

[12] Varghese, M. and Roymon, M.G. (2013) Studies on Antibiotic Resistance Profiles of Thermotolerant Escherichia coli and Multiple Antibiotic Resistance Index of Different Water Sources. Recent Research in Science and Technology, 5, 68-72.

[13] Castillo, F.Y.R., González, F.J.A., Garneau, P., Díaz, F.M., Barrera, A.L.G., Harel, J., et al. (2013) Presence of MultiDrug Resistant Pathogenic Escherichia coli in the San Pedro River Located in the State of Aguascalientes, Mexico. Frontiers in Microbiology, 4, 1-16.

[14] Kariuki, S., Revathi, G., Corkill, J., Kiiru, J., Mwituria, J., Mirza, N., et al. (2005) Original Article Escherichia coli from Community-Acquired Urinary Tract Infections Resistant to Fluoroquinolones and Extended-Spectrum Beta-Lactams. Journal of Infection in Developing Countries, 1, 1-6.

[15] Felicitas, N., Romanus, I.I., Azubuike, A.C., Eze, A.T., Collins, O.N. and Chidiebube, N.A. (2010) Presence of Antibiotic Resistant Coliforms in Sachet Water Sold in Some Parts of South Eastern Nigeria. Journal of Microbiology and Antimicrobials, 2, 51-54.

[16] Fanuncio, L.J.C. and Nuñeza, O.M. (2014) Antibiotic Sensitivity Profile of Escherichia coli in Water Samples from Water Hand Pumps in Selected Areas in Iligan City, Philippines. Advances in Environmental Sciences-International Journal, 6, 1-6.

[17] Debmandal, M., Mandal, S. and Pal, N.K. (2011) Antibiotic Resistance Prevalence and Pattern in Environmental Bacterial Isolates. Open Antimicrobial Agents Journal, 3, 45-52. http://dx.doi.org/10.2174/1876518101103010045

[18] Septage, H., Water, S., Sayah, R.S., Kaneene, J.B., Johnson, Y. and Miller, R. (2005) Patterns of Antimicrobial Resistance Observed in Escherichia coli Isolates Obtained from Domestic- and Wild-Animal Fecal. Applied and Environmental Microbiology, 71, 1394-1404. http://dx.doi.org/10.1128/AEM.71.3.1394-1404.2005

[19] Resistance, A. and Coliform, A. (1976) Antibiotic Resistance among Coliform and Fecal Coliform Bacteria Isolated from the Freshwater Mussel Hydridella menziesii. Antimicrobial Agents and Chemotherapy, 9, 885-888. http://dx.doi.org/10.1128/AAC.9.6.885

[20] Tao, R., Ying, G., Su, H., Zhou, H. and Sidhu, J.P.S. (2010) Detection of Antibiotic Resistance and Tetracycline Resistance Genes in Enterobacteriaceae Isolated from the Pearl Rivers in South China. Environmental Pollution, 158, 2101-1209. http://dx.doi.org/10.1016/j.envpol.2010.03.004

[21] Mohamudha Parveen, R., Harish, B.N. and Parija, S.C. (2010) AmpC Beta Lactamase among Gram Negative Clinical Isolates from a Tertiary Hospital, South India. Brazilian Journal of Microbiology, 41, 596-602.

[22] Sreeshma, P., Champa, H. and Padmaraj, S.R. (2015) An Insight into Antibiogram and $\beta$-Lactamase Production of Pseudomonas aeruginosa Isolated from River Water and Soil. International Journal of Current Microbiology and Applied Sciences, 4, 82-87.

[23] Hryniewicz, W., Gniadkowski, M., Kusza, K. and Gospodarek, E. (2010) Antimicrobial Susceptibility of MetalloBeta-Lactamase Positive and Negative Klebsiella pneumoniae Strains Isolated from Intensive Care Unit Patients. Polish Journal of Microbiology, 59, 67-69.

[24] Leonard, A.F.C., Zhang, L.H., Balfour, A.J., Garside, R. and Gaze, W.H. (2015) Human Recreational Exposure to Antibiotic Resistant Bacteria in Coastal Bathing Waters. Environment International, 82, 2-3.

[25] Arikan, B. and Aygan, A. (2009) Resistance Variations of Third Generation of Cephalosporins in Some of the Enterobacteriaceae Members in Hospital Sewage. International Journal of Agriculture and Biology, 11, 93-96.

[26] Zhang, H. and Chang, W. (2015) Multidrug Resistance Found in Extended-Spectrum Enterobacteriaceae from Rural Water Reservoirs in Guantao, China. Frontiers in Microbiology, 6, 6-9.

[27] Jacobson, K.L., Cohen, S.H., Inciardi, J.F., King, J.H., Lippert, W.E., Iglesias, T., et al. (1995) The Relationship between Antecedent Antibiotic Use and Resistance to Extended-Spectrum Cephalosporins in Group I $\beta$-Lactamase-Producing Organisms. Clinical Infectious Diseases, 21, 11071113. http://cid.oxfordjournals.org/content/21/5/1107.abstract http://dx.doi.org/10.1093/clinids/21.5.1107

[28] Koczura, R., Mokracka, J., Jabłońska, L., Gozdecka, E., Kubek, M. and Kaznowski, A. (2012) Antimicrobial Resistance of Integron-Harboring Escherichia coli Isolates from Clinical Samples, Wastewater Treatment Plant and River Water. Science of the Total Environment, 414, 680-685. http://www.sciencedirect.com/science/article/pii/S0048969711012289

[29] Speldooren, V. and Heym, B. (2000) Epidemiological Survey of Amoxicillin-Clavulanate Resistance and Correspond- 
ing Molecular Mechanisms in Escherichia coli Isolates in France : New Genetic Features of bla $a_{\mathrm{TEM}}$ Genes. Antimicrobial Agents and Chemotherapy, 44, 2709-2714. http://dx.doi.org/10.1128/AAC.44.10.2709-2714.2000

[30] Armstrong, J.L., Shigeno, D.S., Calomiris, J.O.N.J. and Seidler, R.J. (1981) Antibiotic-Resistant Bacteria in Drinking Water. Applied and Environmental Microbiology, 42, 277-283.

[31] Ali, H., Ed, B., Bacha, K. and Ketema, T. (2013) Bacteriological Quality and Antimicrobial Susceptibility of Some Isolates of Well Waters Used for Drinking in Jimma Town, Southwest Ethiopia. Ethiopian Journal of Education and Sciences, 6, 95-108.

[32] Hamelin, K., Bruant, G., El-shaarawi, A., Hill, S., Edge, T.A., Fairbrother, J., et al. (2007) Occurrence of Virulence and Antimicrobial Resistance Genes in Escherichia coli Isolates from Different Aquatic Ecosystems within the St. Clair River and Detroit River Areas. Applied and Environmental Microbiology, 73, 477-484.

[33] Lupo, A., Coyne, S. and Berendonk, T.U. (2012) Origin and Evolution of Antibiotic Resistance: The Common Mechanisms of Emergence and Spread in Water Bodies. Frontiers in Microbiology, 3, 1-13.

[34] Suzuki, S., Thi, P. and Hoa, P. (2012) Distribution of Quinolones, Sulfonamides, Tetracyclines in Aquatic Environment and Antibiotic Resistance in Indochina. Frontiers in Microbiology, 3, 1-8. 